ISSN 1112-9867

\title{
ANTIBACTERIAL ACTIVITY OF LEAVES AND PITCHERS EXTRACT OF NEPENTHES GRACILIS AGAINST BACILLUS SUBTILIS AND ESCHERICHIA COLI
}

\author{
N. N. Rodzali ${ }^{*}$ and M. M. Mydin \\ Faculty of Applied Sciences, UniversitiTeknologi MARA Perak Branch, Tapah Campus, \\ Perak, Malaysia
}

Published online: 10 November 2017

\begin{abstract}
Nepenthes gracilis known as pitcher plant grow mostly in the highland of Malaysia and had been used for ages as traditional medicine for human being. This present study was to evaluate the potential of ethanolic extract of leaf and pitcher of Nepenthes gracilis in antibacterial activity. The antibacterial activity was determined by using agar disk diffusion method against Bacillus subtilis and Escherichia coli. The leaf showed inhibitory activity with the zone of inhibition ranging from $16 \mathrm{~mm}$ to $20 \mathrm{~mm}$ while for pitcher the zone inhibition showed at range $8 \mathrm{~mm}$ to $10 \mathrm{~mm}$ when tested against Escherichia coli. Whereas, the leaf and pitcher extract showed inhibitory activity of zone inhibition ranging from $12 \mathrm{~mm}$ to $20 \mathrm{~mm}$ and $8 \mathrm{~mm}$ to $12 \mathrm{~mm}$ respectively when tested against Bacillus subtilis. The phytochemical screening for both leaf and pitcher extract showed the presence of saponin, flavonoid, phenol and glycoside.
\end{abstract}

Keywords: Nepenthes gracilis; antibacterial activity.

Author Correspondence, e-mail: nurnadirah@perak.uitm.edu.my

doi: http://dx.doi.org/10.4314/jfas.v9i6s.7 


\section{INTRODUCTION}

Carnivorous plants display the particularity of living in nutrient poor soils and they have avoid this shortage of resources by developing leaves in the form of traps that are adapted to catch prey [1]. Nepenthes pitchers known to be passive traps however, various strategies have been developed by the plant to attract, catch and digest prey. The carnivorous syndrome made possible because of many bioactive compounds that are secreted by the pitcher [2]. Among the seven genera of pitcher plants, Nepenthes is the largest genus and mostly distributed in the Malaysia region, with its highest diversity occurring in Borneo [3].The genus Nepenthes pitcher has ability to trap insects and digest them in the contained fluid, which has long been thought to contain digestive enzymes to gain nutrient [4]. The inside wall is also slippery and waxy to prevent insects from escape [5].

Nepenthes species had been used traditionally to cure numerous illnesses. Their medicinal uses include remedies developed from the roots for stomach aches, whereas the pitcher had been used for the treatment of diabetes [6]. Investigations of the pitcher fluids of Nepenthes indicated that the fluids were unsuitable for microbial growth.Thus, Nepenthes plants can avoid and control at least to some extent the microbial colonization of their pitfall traps and thereby reduce the need to vie with microbes for the prey-derived nutrients [7]. The most common species used in traditional medicine are Nepenthes ampullaria and Nepenthes gracillis where the liquid of unopened pitchers are administered to regulate the menstrual cycle, ease child birth, relieve asthma, treat eye inflammation and act as a stamina booster [8-9].

Bacillus subtilis refer to stretch gram-positive and chained bacilli with the size of $0.8-0.7 / 2-3$ um, the nonpathogenic bacteria which exists as a normal flora in the human gastrointestinal system [10]. It can induce disorder in mammalian membrane systems due to the production of lecithinase enzyme in opportunistic cases. Moreover, it produces an extracellular toxin called Subtilisin that causes allergic reactions in humans. This bacterium can contaminate food but it rarely causes food poisoning [11]. Escherichia coli is one of the most extensively studied Gram-negative bacteria in microbiology. This species has been associated with intestinal and extraintestinal infections in humans and many animals [12]. Escherichia coli occurs largely in tropical region, but its outbreaks have been reported in subtropical region [13]. 
This study was conducted to evaluate the potential of Nepenthes gracilis extraction for antibacterial activity. The leaf and the pitcher extraction were used to determine the inhibition zone against Bacillus subtilis and Escherichia coli using agar disk diffusion method. The phytochemical screening for the extraction was done to observe the secondary metabolite that present in the extraction.

\section{EXPERIMENTAL}

\subsection{Sample Preparation}

The Nepenthes gracilis plants were bought from Forest Research Institute Malaysia (FRIM) Kepong. The leaf and the pitcher have been leave to dry in the oven. The dried leaf and pitcher were grind by using grinding machine until powdery form.

\subsection{Extraction of Leaf and Pitcher}

The leaf and pitcher powder were weighed to $6.25 \mathrm{~g}$ and were immersed in $250 \mathrm{ml}$ of $99.8 \%$ ethyl alcohol in beaker for 3 days respectively. Each extraction were filter by using filter paper and evaporated into concentrated extract by using rotary evaporator at $60^{\circ} \mathrm{C}$.

\subsection{Preparation of Nutrient Agar}

$20 \mathrm{~g}$ of nutrient agar powder was weighed and being added into $1 \mathrm{~L}$ of distilled water. The mixture was heated until the solution became clear. The mixture then was autoclaved at $121^{\circ} \mathrm{C}$ for 30 minutes and allowed to cool down to $50^{\circ} \mathrm{C}$. The nutrient agar was poured into petri dish with an average of 25-35 $\mathrm{ml}$ per petri dish.

\subsection{Preparation of Nutrient Broth}

$14 \mathrm{~g}$ of nutrient broth powder were weighed and be added into $1 \mathrm{~L}$ distilled water. The mixture was separated into four $50 \mathrm{ml}$ glass bottle. Then, each of the mixture was stirred using magnetic stirrer to obtain homogenous mixture of nutrient broth. The mixture then was autoclaved at $121^{\circ} \mathrm{C}$ fo 30 minutes.

\subsection{Preparation of Standard Inoculum}

$50 \mathrm{ml}$ of nutrient broth was measured and poured into $250 \mathrm{ml}$ conical flask. Then, a loop full of Bacillus subtilis was taken from agar nutrient plate by using inoculating loop and was dipped in nutrient broth. The mouth of conical flask wascovered than was incubated at $35^{\circ} \mathrm{C}$ for 24 hours. All the nutrient broth containing Bacillus subtilis were pipetted into centrifuge 
tubes using 100-1000 $\mu$ Lmicropippete and the volume of the mixture was fixed at $1.5 \mathrm{ml}$ per tube. Then the tubes were centrifuge at $5000 \mathrm{rpm}$ for 15 minutes at $4^{\circ} \mathrm{C}$. The sendiment was diluted with $500 \mu \mathrm{L}$ of $0.7 \%$ Sodium chloride $(\mathrm{NaCl})$ solution. The absorbance of Bacillus subtilis was checked using spectrophotometer to achieved 0.5 A. $300 \mu \mathrm{L}$ of 0.5 A Bacillus subtilis was poured in agar plate then was spread evenly. All the steps repeated using Escherichia coli.

\subsection{Antibacterial Activity}

Antibacterial activity were determined by the agar diffusion method using filter paper disks. Four disks were placed on top of agar containing Bacillus subtilis and Escherichia coli. The first disk was diffused with $20 \mu \mathrm{L}$ of antiseptic solution as a positive control. The second disk was diffused by $20 \mu \mathrm{L}$ of distilled water as negative control. The third and fourth disks were diffused with $20 \mu \mathrm{L}$ of Nepenthes gracilis leaf and the pitcher extraction respectively. Six petri dish been prepared for both tested bacteria. All the agar plates were incubated at $35^{\circ} \mathrm{C}$ for 24 hours. The average of inhibition zone for both were recorded.

\subsection{Phytochemical Screening}

\subsubsection{Test for Saponins}

The leaf and pitcher extract were dilute in $3 \mathrm{ml}$ of distilled water. Next, $1 \mathrm{ml}$ of the mixture was shook by using a test tube with cap for 15 minutes. The presences of $1 \mathrm{~cm}$ layer of foam was observed

\subsubsection{Test for Flavonoids}

$2 \mathrm{ml}$ of leaf and pitcher diluted extract were poured in a test tube. A few drops of diluted sodium hydroxide were added in followed by a few drops of diluted hydrochloric acid. The change of intense yellow colour was observed.

\subsubsection{Test for Phenols}

A few drops of $5 \%$ Iron chloride $\left(\mathrm{FeCl}_{3}\right)$ solution was added to $2 \mathrm{ml}$ of each leaf and pitcher extract. The intense colour change of mixture were observed.

\subsubsection{Test for Glycosides}

$2 \mathrm{ml}$ of each leaf and pitcher extract was added with $2 \mathrm{ml}$ of glacial acetic acid, a drop of 5\% Iron chloride $\left(\mathrm{FeCl}_{3}\right)$ and a drop of concentrated sulphuric acid $\left(\mathrm{H}_{2} \mathrm{SO}_{4}\right)$. The appearance of brown ring was observed. 


\section{RESULTS AND DISCUSSION}

The study investigated an antibacterial activity of Nepenthes gracilis leaf and the pitcher extracted against tested bacteria, Bacillus subtilis and Escherichia coli. The extraction of the leaf of Nepenthes gracilis give the average of inhibition zone slightly higher for Bacillus subtilis compared with Escherichia coli with $19 \mathrm{~mm}$ and $17 \mathrm{~mm}$ respectively. The inhibition zone for Nepenthes gracilis pitcher extracted showed the average of $11 \mathrm{~mm}$ inhibition zone for Bacillus subtilis and $9 \mathrm{~mm}$ inhibition zone for Escherichia coli. The results shown in Table 1 and Table 2.

Table 1.Antibacterial activity of Nepenthes gracilis against Bacillus subtilis

\begin{tabular}{ccccc}
\hline & \multicolumn{4}{c}{ The Diameter of Inhibition Zone (mm) } \\
& Pitcher & Leaf & Positive & Negative \\
\hline Plate & 11 & 19 & 16 & 0 \\
\hline Table 2. Antibacterial activity of & Nepenthes gracilis against Escherichia coli \\
\hline \multicolumn{5}{c}{ The Diameter of Inhibition Zone (mm) } \\
& Pitcher & Leaf & Positive & Negative \\
\hline Plate & 9 & 17 & 14 & 0 \\
\hline
\end{tabular}

The Fig. 1 and Fig. 2 show the inhibition zone for leaf extract, pitcher extract, positive control and negative control for each tested bacteria. The up left shows the inhibition zone for pitcher extract, while the up right shows the inhibition zone for leaf extract (based on figure). For both bacteria tested, leaf extract inhibit more bacteria compare to the pitcher extract.

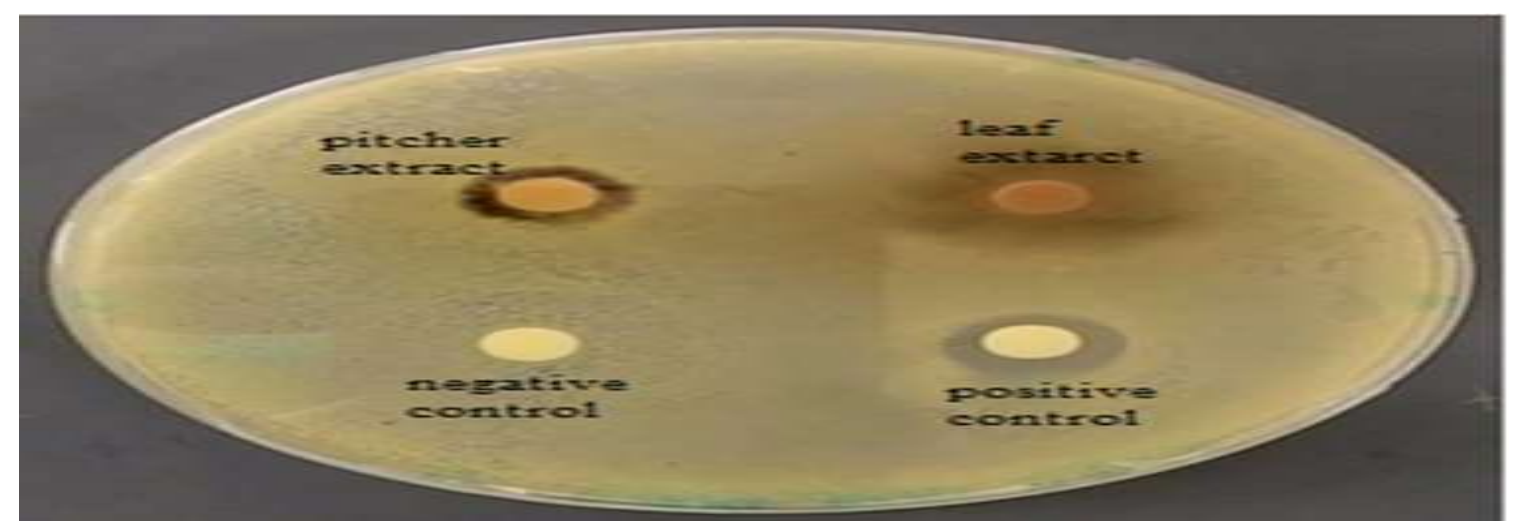

Fig.1. Inhibition zone for Bacillus subtilis 


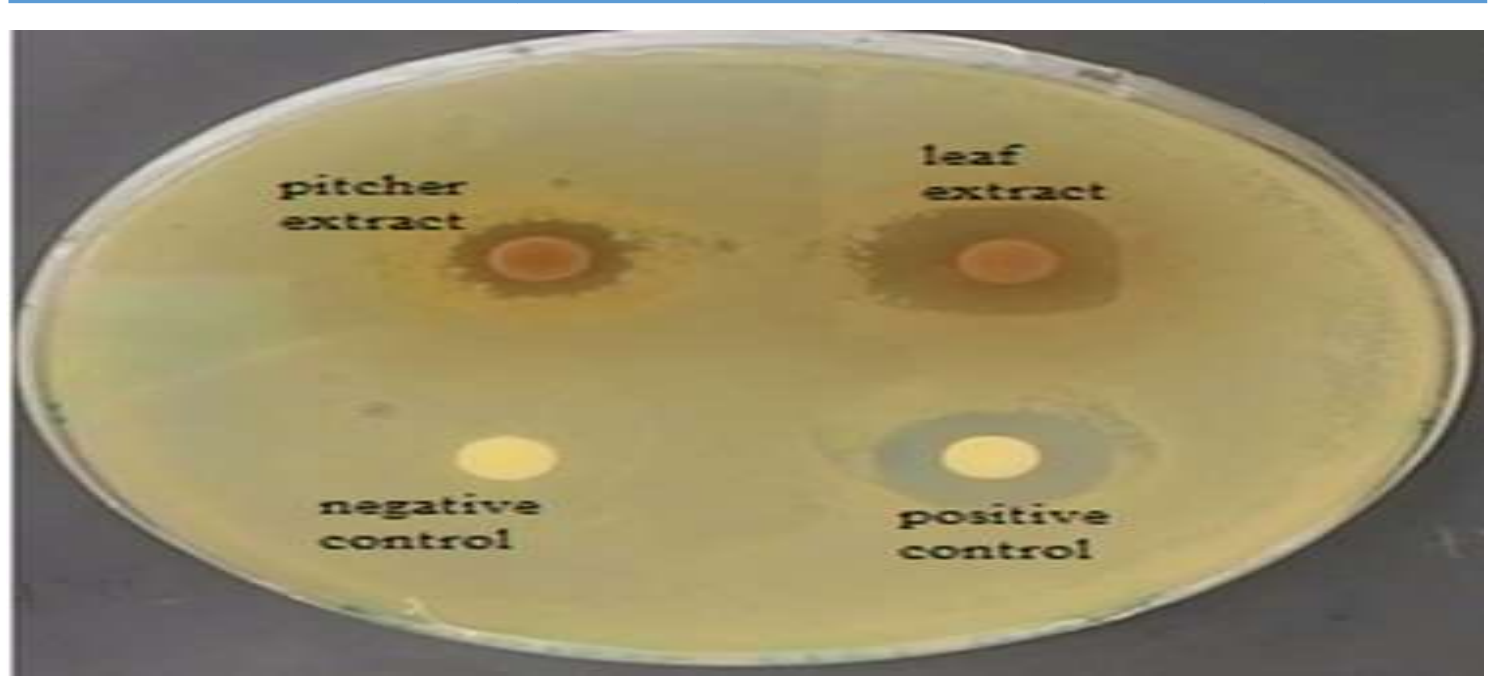

Fig.2.Inhibition zone for Escherichia coli

The inhibition zone for each extract and controls have been done by measuring the diameter of the disk. From the result itsshowed that both the leaf and pitcher of Nepenthes gracilis are able to inhibit the growth of tested bacteria. The inhibition zone of the both extracted are comparable with the inhibition zone for positive control.

The screening for phytochemical of the leaf and pitcher extract of Nepenthes gracilis qualitatively revealed the presence of various secondary metabolites which includedsaponins, flavonoid, phenols and glycoside (Table 3).

Table 3. Phytochemical detected in the pitcher and leaf extract

\begin{tabular}{ccc}
\hline Phytochemical & \multicolumn{2}{c}{ Result } \\
& Pitcher & Leaf \\
\hline Saponins & + & + \\
Flavonoids & + & + \\
Phenols & + & + \\
Glycosides & + & +
\end{tabular}

These secondary metabolite had been believed that cause of the inhibition of bacteria. The study by [14] shows that the phytochemical content in Nepenthes gracilis including quercetin, naphthoquinone and cyanidin which under phenolic and flavonoid group. It can be related since quercetin gives a strong inhibitory effect against Bacillus subtilis and Escherichia coli [15]. Many saponins are well known to be antimicrobial, inhibit mould, and to protect plants from insect attack [16]. The extracted shown the present of saponins that can be well said to inhibit the bacteria. 


\section{CONCLUSION}

In conclusion, both of pitcher and leaf extract of Nepenthes gracilis shows the antibacterial activity by inhibiting growth of Bacillus subtilis and Escherichia coli in agar diffusion method. The inhibition zone for both extracted comparable with the zone inhibition of positive control (antiseptic). The screening for both extract shows the phytochemical compound including saponins, flavonoid, phenols and glycoside. This research suggests the potency of leaf and pitcher extract of Nepenthes gracilis as alternative sources to control bacteria.

\section{ACKNOWLEDGEMENTS}

We wish to thank Forest Research Institute Malaysia (FRIM) Kepong and the staff of Molecular Biology Lab from Faculty of Applied Science, UiTM Perak Branch, Tapah Campus.

\section{REFERENCES}

[1] Biteau N, Nisse E, Miguel S, Hannnewald P, Bazile V, Gaume L, Mignard B, Hehn A, Bourdgaud F. A simple SDS-PAGE protein pattern from pitcher secretions as a new tool to distinguish nepenthes species (nepenthaceae). American Journal of Botany, 2013, 100(12):2478-2484

[2] Mithöfer A. Carnivorous pitcher plants: Insights in an old topic: A review. Phytochemistry, 2011, 72(13):1678-1682

[3] Clarke C. Nepenthes of Borneo. Sabah: Natural Histrory Publications, 2006

[4] Takeuchi Y, Salcher M M, Ushio M, Shimizu I R, Kobayashi J K, Diway B, Mering V C, Pernthaler J, Shimizu KK. In situ enzyme activity in the dissolved and particulate fraction of the fluid from four pitcher plant species of the genus nepenthes. Plos One, 2011, 6(9):1-10

[5] Hatano N, Hamada T. Proteomic analysis of secreted protein induced by a component of prey in pitcher fluid of the carnivorous plant Nepenthes alata. Journal of Proteomics, 2012, 75(15):4844-4852

[6] Sudhir K. The medicinal plants of North-East India. Rajasthan: Scientific Publishers, 2002

[7] Buch F, Rott M, Rottloff S, Paetz C, Hilke I, Raessler M, Mithöfer A. Secreted pitfall-trap 
fluid of carnivorous Nepenthes plants is unsuitable for microbial growth. Annals of Botany, $2012,111(3): 375-383$

[8] Wong C. Medicinal plants of Brunei Darussalam. Brunei Darussalam: Ministry of Industry and Primary Resources, 2000

[9] Ismail N A, Kamariah A S, Lim L B L, Ahmad N. Phytochemical and pharmacological evaluation of methanolic extracts of the leaves of Nepenthes bicalcarata Hook. F. International Journal of Pharmacognosy and Phytochemical Research, 2015, 7(6):1127-1138

[10] Saleh F, Kheirandish F, Azizi H, Azizi M. Molecular diagnosis and characterization of Bacillus subtilis isolated from burn wound in Iran. Research in Molecular Medicine, 2014, $2(2): 40-44$

[11] Nicolas P, Mader U, Dervyn E, Rochat T, Leduc A, Pigeonneau N, Bidnenko E, Marchadier E, Hoebeke M, Aymerich S, Becher D.Condition-dependent transcriptome reveals high-level regulatory architecture in Bacillus subtilis. Science, 2012, 335(6072):1103-1106 [12]Kaper J B, Nataro J P, Mobley H L. Pathogenic escherichia coli. Nature Reviews Microbiology, 2004, 2(2):123-140

[13]Escobar P P, Grenet K, Le Menac'h A, Rode L, Salgado E, Amorin C, Gouriou S, Picard B, Rahimy M C, Andremont A. Large-scale population structure of human commensal Escherichia coli isolates. Applied Environmental Microbiology, 2004, 70(9):5698-5700

[14] Adam J H, Omar R, Wilcock C C. phytochemical screening of flavonoids in three hybrids of nepenthes (nepenthaceae) and their putative parental species from Sarawak and Sabah. Online Journal of Biology Sciences, 2002, 2(9):623-625

[15]Abd-Allah W E, Awad H M, AbdelMohsen MM. HPLC analysis of quercetin and antimicribial activity of comparative methanol extracts of shinusmolle L. International Journal of Current of Microbiology and Applied Sciences, 2015, 4(11):550-558

[16] Francis G, Kerem Z, Harinder P S M, Klaus B. The biological action of saponins in animal systems: A review. British Journal of Nutrition, 2002, 88(6):587-605

\section{How to cite this article:}

Rodzali N N, Mydin M M. Antibacterial activity of leaves and pitchers extract of nepenthes gracilis against bacillus subtilis and escherichia coli. J. Fundam. Appl. Sci., 2017, 9(6S), $81-88$. 